Literatura y Lingüística $\mathrm{N}^{\circ} 24$

ISSN 0716-5811 / pp. 243-246

\title{
Frío en la noche latina
}

\author{
Pablo Paredes \\ Editorial [Contrabando del bando en contra]. \\ Santiago de Chile, 2005, 113p.
}

Uno de los últimos pequeños vuelos de Altazor (paracaídas arriba o abajo), aterrizó en el creador de Desdicha Obrera, 2007 (obra original de Luis Emilio Recabarren), Curarse, 2009, Las enfermitas sagradas de Chile, 2009 y, Las analfebetas, 2010, entre otras. Pablo Paredes Muñoz (1982), poeta y dramaturgo, insolentemente joven, ha demostrado durante los últimos diez años, cuando menos, un oficioso camino estético; de la poesía (paradójicamente con mucha fe) al drama, del verso breve al vertiginoso ritmo subordinante y clausular; de Paredes a Paredes, en suma. Sus formas siempre expansivas, su palabra siempre en repliegue y avance hasta la claridad poética de todo un proceso literario, crítico y fenomenológico en que subsiste, a veces, la silenciosa rabia de los torturados por el símbolo. Ineludible resulta su producción ficcional-sígnica, por cierto- en cualquiera de sus representaciones. Es por eso que, pese a que ha destacado el último tiempo en la dramaturgia, se reseñará a continuación su inicial producción poética, puntualmente, la Antología Frío en la noche Latina (2005) por cuanto permite ésta panoramizar su producción pre-drama.

1973, año clave en (para) la cultura y la memoria histórica de Chile. La poesía sufre, como muchos otros agentes del circuito intelectual del país (y de América), una castración simbólica que, como sugiriera Richard, instala en el ambiente estético la hegemonía de lo residual. La patria entonces, amputada y dividida, se transformó en lugar sitiado por retobos y exequias. Consecuencia: devendría el ciclo de la insubordinación, la cancelación del tiempo y la creación alegórica; la búsqueda de lo ido. Ya no existe el símbolo porque no hay nada que representar, el símbolo es momentáneo y lo momentáneo en Chile no es más que una historia sufriente, lo que queda es re-construir, re-definir un proyecto cultural desde un pasado ruinoso. Queda un cuerpo dañado, una imagen de niño-niña donde se recodifica la estética del dolor.

La resistencia poética y la erotización de esos detrimentos proyectados desde el cuerpo-ciudad son la clave del discurso poético de los 70` y 80”, heredado luego por el naufragio noventero y materializado en el discurso 
del fracaso. Suma y sigue más o menos así: nos desgarró la dictadura, nos vino encima la democracia, pero nadie se hizo cargo de los pesares del país. Si el discurso ha fracasado, también lo hacen los sujetos discursivos y, en consecuencia, a la poesía no le queda más remedio que buscar nuevas formas de re-presentación en la barriada que nos devora.

No a las respetables putas de la belleza/ No a los distinguidos perros de la poesía/ Nosotros hemos cantado a nuestra generación sin lograr despertarlos del miedo. (Hernández: 2000).

Cuando se niega la belleza, se niega un canon no casualmente impuesto por aquellos que Hernández sindica como perros de la poesía. En ésa, su negación, está la ruptura además de una sensación generacional, está la prefiguración de un nuevo escenario cultural (o escena, si se prefiere) que pretende despertar a los sujetos del miedo y remover las viscosidades de una ciudad lejana e inmadura. En tales coordenadas imaginadas emerge Frío en la noche Latina (2005), la antología de Pablo Paredes que se inserta y provoca; sugiere y critica.

Espacios de recuperación; el frío de siempre. La noche latina, el vacío y la alucinación: eso es la poesía de Paredes, un proyecto poético en que se hibrida el texto y la cultura apuntando a una lógica de re-codificación desde la infancia y re-instalando el barrio en la metáfora de un país/ continente de rabias y desperdicios.

Así se evidencia, al menos, en El barrio de los niños malos (2001), [libro figurante en la reseñada antología de Pablo Paredes], donde se re-construye con tono épico el silencio, el retorno a lo extraviado, la valoración de los espacios perdidos en el gran discurso democrático o en la bulla del llanto poblacional. Su poesía es espejo del tránsito, ingenuo y desgarrante, de la historia: "El día que se fue la infancia dejé de llorar moviendo las costillas" (Paredes: 16).

Se poetiza la infancia porque la infancia es lo perdido, es el siervo de una imagen social en (de)formación. El barrio es una categoría de la ciudad, y la ciudad aplasta la infancia; es la dialéctica de los subordinados y los subordinantes, la evidencia alegórica de la castración del país y del continente; por eso en el país y en América siempre es de noche, siempre es de tumba, de féretro. El sitio barrial es una categoría fenomenológica de los vacíos en que coexiste lo marginal y la decadencia homérica de los antihéroes.

Así como el barrio, quizá la infancia sea sólo un estado del fenómeno, un movimiento en la metáfora del sujeto; un estadio en que nos dejamos 
engolosinar por la democracia noventera y nuevo-milenaria. Presagio y producto: la esquina, triste espacio de todos, emerge en el discurso. Pantys Rotas (2004) y Final de la fiesta (2004) lo demuestran, por cuanto construyen una hibridación texto-cultura y recurren a la poetización de ciertos referentes mediáticos que cumplen la función de desmitificar lo canónico y devolver la poesía y sus referentes al mismo pueblo que se halla deprivado por la violencia simbólico-cultural.

En la construcción de una ética alternativa (desde el discurso) surge Gloria Trevi, Lady Di, el engaño de la televisión, el Rock y el Pop de su infancia, la Blondie, los Juegos Diana, la cumbia, Jennifer López; todo en perfecta conjunción con los tópicos paredianos y el vértigo de su sígnica poética:

Te traje un día a mi ciudad que está en la esquina a ver los monos verdes bailando cumbia [... y y bailamos la noche latina con las patitas rajando el infierno [... y y eras el video de Jennifer López. (Paredes: 53)

El ruido de la cumbia viene a hacerse cargo de la muerte. Los referentes extraliterarios son el recurso que lo evidencia; el rescate de la belleza pop con las figuras antes nombradas es el corolario de una estética que, como siempre, alegoriza América y sus desastres:

He pasado la noche en Amérika [...] miraba todo lo rubio que sucedía, la orina muerta desbordándose, los ojos de polvo de los chicos, las caderitas rasguñadas de las chicas, me imaginé que era Chayane y después Paulina Rubio y un rato Sandro [...] hoy es fiesta en Amérika y ya no estoy (Paredes:2005).

Esos lugares del claustro son los bordes donde se desplazan los sujetos, los gestores de una nueva autoformación marginal: los nominalizados por el imaginario de su poesía; síndrome épico de los que sobran.

Si la infancia es sólo un estado del fenómeno, un tránsito en la metáfora del país, entonces las ruinas de la modernidad, o la posmodernidad, son el contexto tecnologizado donde el sujeto es parte de la inmediatez y el abandono de la identidad. Los fenómenos políticos permitieron la expansión y exploración de sugerentes espacios poéticos más allá del cuerpo.

La crítica de Paredes apunta hacia la construcción cultural y su devenir ético. Por ello, en Los pájaros (2004), se instala una nueva deformación del hombre: el pájaro simboliza la transición desde la infancia precaria (que ha generado, como la razón, monstruos de un sueño prestado) hacia el mapa urbano que invierte todos los sentidos del hombre; una 
pequeña libertad vedada.

Los gorriones están contentos porque ya no les pegan, los gorriones engordan y se ponen plomos. Yo soy de ésos: pájaro chico monstruoso (Paredes: 77).

Más allá de los títulos, una detención panorámica en el texto antológico como unidad, conmina no a fraccionar la lectura sino a edificar un constructo estético complejo: el tono apocalíptico, la manifestación de los poderes centrales sobre los sujetos habitantes de la ciudad (Evangelios: 2003) y la referida recuperación de espacios simbólicos, son la crítica a la serie de gestaciones caóticas y capitales, al drama laboral y a la emergencia de una clase media que se ha estancado en los avatares de la globalización.

No se trata de su poesía, sino de su proyecto poético. La voz es la metonimia del Mano de obra, del Cuerpo dañado, el gran símbolo del retorno a lo deshecho del desecho, a lo que debe reconstruirse desde los lugares heridos, ya sea desde la infancia, del barrio, del cuerpo, de la memoria o del mismo sujeto en conflicto; debe re-codificarse desde lo arrebatado al hombre americano que ahora padece de frío, que ahora subsiste en la incertidumbre de alguna fría noche latina.

Dile [mami] que no sirvo, que soy caca, que tú me cagaste y como te dio pena me pusiste un nombre (Paredes: 40).

Ricardo Sánchez

Pedagogía en Castellano

Universidad Católica Silva Henríquez 